\title{
Prescribing of potentially harmful drugs to patients admitted to hospital after head injury
}

\author{
Larry B Goldstein
}

\begin{abstract}
Fundamental studies in laboratory animals show that certain drugs influence behavioural recovery after brain injury. Although some drugs have the potential to enhance recovery, others may be detrimental. The purpose of the present study was to determine how often these potentially detrimental drugs are used in the management of patients with traumatic brain injury. The medical records of 100 patients with head trauma admitted to a university hospital during one year were reviewed and the frequencies of medication prescriptions during the stay in hospital were recorded. Only 14\% of patients with head injury were taking medications at the time of injury. All of the patients were prescribed medications during their stay in hospital. Seventy two per cent of the patients received one or a combination of the drugs (neuroleptics and other central dopamine receptor antagonists, benzodiazepines, and the anticonvulsants phenytoin and phenobarbitone) that animal studies suggest may impair recovery. Until the true impact of these classes of drugs on the recovery process is better understood, care should be exercised in their use.
\end{abstract}

$(\mathcal{F}$ Neurol Neurosurg Psychiatry 1995;58:753-755)

Keywords: head trauma; recovery

Traumatic brain injury affects 200 to 400 persons per 100000 population in the United States and has a peak incidence in the second and third decades of life. ${ }^{1}$ A second peak in incidence occurs in the sixth decade. ${ }^{1}$ Although $5 \%-10 \%$ of traumatic brain injury cases are fatal (overall mortality of 25 per 100000 population), most people have only minor injuries and do not come to medical attention. ${ }^{1}$ Moderate head injury (Glasgow coma scale 9-12) affects 60-75000 persons each year. ${ }^{2}$ Of patients with moderate traumatic brain injury, two thirds are moderately to severely disabled three months after the injury. ${ }^{3}$

Potential interventions for traumatic brain injury generally consist of primary prevention, reduction of acute sequelae, and rehabilita- tion. It is clear, however, from recent laboratory studies that recovery after focal brain injury can be affected by certain drugs that influence the activities of specific central neurotransmitters. ${ }^{45}$ Even small doses of some drugs given after brain injury can have long lasting beneficial or harmful effects on recovery. ${ }^{6-8}$ For example, amphetamine is among the most extensively studied drugs with the capacity to facilitate recovery after focal brain injury. ${ }^{6-15}$ Coadministration of haloperidol blocks amphetamine promoted recovery and haloperidol impairs recovery when given alone. ${ }^{616}$ Treatment with a centrally acting $a_{1}$ adrenergic receptor antagonist (prazosin) interferes with motor recovery after focal sensorimotor cortex injury in rats. ${ }^{17}$ Postlesion systemic administration of an $a_{2}$ adrenergic receptor antagonist (yohimbine, idazoxan) is beneficial ${ }^{17-20}$ whereas the $a_{2}$ adrenergic receptor agonist clonidine impairs motor recovery when given soon after brain injury ${ }^{7}$ and reinstates motor deficits in recovered rats. ${ }^{172021}$ Intracortical infusion of the inhibitory neurotransmitter $\gamma$ aminobutyric acid (GABA) increases the hemiparesis produced by a small motor cortex lesion in rats. ${ }^{22}$ The deleterious effect of GABA is increased by the systemic administration of phenytoin, ${ }^{23}$ which may act through a GABA mediated mechanism. ${ }^{24}$ The short term administration of diazepam, a benzodiazepine that acts as an indirect GABA agonist, permanently impedes recovery from the sensory asymmetry caused by anteromedial neocortex damage in rats. ${ }^{8}$ Phenobarbitone administration to rats recovering from cortical injury is also detrimental ${ }^{25}$ whereas carbamazepine does not influence the recovery process. ${ }^{26}$ Drugs affecting acetylcholine and glutamate may also influence recovery. ${ }^{27-30}$ Certain of the new experimental neuroprotective agents may actually be harmful if given at particular times during the recovery process. ${ }^{30} 31$

Preliminary clinical evidence suggests that the same drugs that influence recovery in laboratory animals may also affect recovery in humans after both stroke ${ }^{32-36}$ and traumatic brain injury. ${ }^{37-39}$ Many of the possibly harmful drugs identified through laboratory investigations (the antihypertensives clonidine and prazosin, neuroleptics and other central dopamine receptor antagonists, benzodiazepines, and the anticonvulsants phenytoin and in revised form

Accepted 10 January 1995 
and phenobarbitone) are commonly prescribed for stroke patients for the treatment of coincident medical problems. ${ }^{40}$ The purpose of the present retrospective study was to determine how often these potentially detrimental drugs are used in the management of a group of patients with traumatic brain injury.

\section{Patients and methods}

Patients with head trauma admitted to Duke University Hospital between 1 January and 31 December 1990 were identified through a prospective registry. A retrospective chart review was then carried out to determine what drugs were prescribed for these patients during their stays in hospital. A variety of clinical variables were also recorded including age, sex, race, medical history, admission Glasgow coma score (GCS), ${ }^{41}$ brain CT findings, the occurrence of postinjury seizures, and whether craniotomy or other surgery was performed.

$\chi^{2}$ tests were used for statistical comparisons of categorical data. The Mann-Whitney $U$ test was used for ordinal, non-continuous data. Student's $t$ test was used for continuous, normally distributed data.

\section{Results}

One hundred and five patients were identified through the registry. Hospital charts could not be located for five patients. Of the remaining 100 patients, there were 72 men and 28 women. Sixty six per cent of the patients were white. Most of the remainder (31\% of the total) were African-American. The mean age of the patients was 38 years. Fourteen patients died while in hospital and one was prematurely discharged against the advice of his physicians. As expected, the median admission Glasgow coma score of those who died was significantly lower than for those who survived $(3.0 v 13.5$,

Drugs prescribed for more than $10 \%$ of patients in hospital after head injury $(n=85)$

\begin{tabular}{|c|c|}
\hline Drug class & $\begin{array}{l}\text { Patients } \\
\text { prescribed } \\
(n(\%))\end{array}$ \\
\hline $\begin{array}{l}\text { Narcotic } \\
\text { Paracetamol } \\
\text { Antibiotic } \\
\text { Neuroleptic/dopamine antagonist }{ }^{\star} \\
\text { Promethazine } \\
\text { Metoclopramide } \\
\text { Haloperidol } \\
\text { Combination } \\
\text { Prochlorperazine } \\
\text { Ranitidine } \\
\text { Benzodiazepine } \\
\text { Miscellaneous antacid } \\
\text { Anticonvulsant } \\
\text { Phenytoin } \dagger \\
\text { Carbamazepine } \\
\text { Phenytoint }+ \text { phenobarbitone } \dagger \\
\text { Carbamazepine + phenobarbitone } † \\
\text { Cimetidine } \\
\text { Other sedative-hypnotic } \\
\text { Other non-narcotic analgesic } \\
\text { Bromocriptine }\end{array}$ & $\begin{array}{l}71(84) \\
70(82) \\
62(73) \\
41(48) \\
21(25) \\
9(11) \\
6(7) \\
4(5) \\
1(1) \\
37(44) \\
34(40) \\
30(35) \\
20(24) \\
16(19) \\
1(1) \\
1(1) \\
2(2) \\
14(16) \\
13(15) \\
13(15) \\
9(11)\end{array}$ \\
\hline
\end{tabular}

$P<0.001)$. There were no differences in survival based on racial group, sex, age, or whether craniotomy or other surgical procedures were performed during the stay in hospital ( $P>0.05$ for each comparison).

The mean duration of stay in hospital of the 85 survivors was 21 (range 1-129) days. Seventy per cent of survivors were male and $64 \%$ were white. Seventy one per cent had closed head injury, $27 \%$ had an associated skull fracture, and $2 \%$ had a gunshot wound. Twenty one per cent of these patients underwent craniotomy and $23 \%$ had other operations. Eight per cent of patients had a history of seizures and $16 \%$ had seizures during the postinjury period in hospital. There was no significant difference in the incidence of seizures after injury between those with and without a history of seizures $(2 \% v 11 \%$, $\mathrm{P}=0 \cdot 7$ ).

Only $14 \%$ of patients with head injury were noted in their hospital records to have been taking medications at the time of injury. All of the patients were prescribed medications during the stay in hospital. The table gives the frequency of prescription by class for drugs given to more than $10 \%$ of the patients. Anaesthetic agents used during surgical procedures and drugs used for the treatment of cerebral edema (mannitol, frusemide) are excluded from the list. The benzodiazepines were the drugs most often prescribed which, based on laboratory studies, might impair recovery after brain injury (given to $40 \%$ of the patients). Almost half of the patients were given either a neuroleptic or another centrally acting dopamine receptor antagonist. Of the 20 patients given anticonvulsants, 17 received phenytoin and three received phenobarbitone (alone or in combination with other anticonvulsant medications). Thus a total of $72 \%$ of patients received one or a combination of potentially detrimental medications. Twenty nine patients $(34 \%)$ were prescribed a single and $32(38 \%)$ were prescribed a combination of these agents.

\section{Discussion}

The primary finding of the present study is that certain classes of drugs found to impair recovery after brain injury in studies with laboratory animals are often prescribed for patients with head injury (neuroleptics and other central dopamine receptor antagonists, benzodiazepines, and the anticonvulsants phenytoin and phenobarbitone). Whether the detrimental effects of specific drugs anticipated from laboratory studies also occurs in humans recovering from brain injury is difficult to determine. One study found that long term administration of phenytoin for prophylaxis of post-traumatic seizures may be detrimental. ${ }^{39}$ Both phenytoin and carbamazepine may have negative effects on cognitive performance in patients recovering from brain trauma. ${ }^{42}$ The duration of post-traumatic amnesia and agitation was longer in patients treated with haloperidol than in 
those managed without this drug. ${ }^{43}$ Clinical data relating to the potential beneficial effects of certain drugs on recovery after traumatic brain injury is also limited. Anecdotal reports indicate that treatment with amphetamine improves cognitive function in young adults with post-traumatic organic brain syndrome..$^{3844}$ Both amantadine ${ }^{45}$ and levodop $\mathrm{a}^{37}$ have been used in the treatment of small groups of patients with severe traumatic brain injury.

In summary, it is clear that certain drugs influence behavioural recovery in laboratory animals after brain injury. These drug effects can be either beneficial or detrimental. Similar drug effects may occur in humans. Certain of the drugs found to be harmful in laboratory studies are commonly employed in the management of the patient with head injury. Whenever clinically feasible, drugs not known to impair recovery should be used in place of those with potentially detrimental effects (for example, carbamazepine could be given in place of the anticonvulsants phenytoin or phenobarbitone if parenteral administration is not required; hydroxyzine could be used in place of benzodiazepines or neuroleptics for agitation). Although prescription of specific drugs is dictated by overriding medical concerns, care should be exercised in their use until their true impact on the recovery process is better understood. I am indebted to A G Haas RN who provided a list of patients
from the Duke Head injury registry and to A Perry, RN who abstracted the data from the patient's medical records.

1 Frankowski RF, Annegers JF, Whitman S. Epidemiological and descriptive studies part I: the descriptive epidemiology of head trauma in the United
States. In: Becker DP, Povlishock JT, eds. Central nervous system trauma status report-1985. Bethesda: National Institutes of Health, 1985:33-43.

2 Marshall LF, Marshall SB. Epidemiological and descriptive studies. Part II: current clinical head injury research in the United States. In: Becker DP, Porlishock JJ, eds. in the United States. In: Becker DP, Porlishock JJ, eds.
Central nervous system trauma status report-1985. Central nervous system trauma status report-1985.

3 Rimel RW, Giordani MA, Barth TJ, Jane JA. Moderate head injury: completing the clinical spectrum of brain trauma. Neurosurgery 1982;11:344-51.

4 Feeney DM, Sutton RL. Pharmacotherapy for recovery of function after brain injury. CRC Critical Reviews in Neurobiology 1987;3:135-97.

5 Goldstein LB. Basic and clinical studies of pharmacologic effects on recovery from brain injury. $f$ Neural Transplant Plast 1993;4:175-92.

6 Feeney DM, Gonzalez A, Law WA. Amphetamine haloperidol and experience interact to affect the rate of recovery after motor cortex injury. Science 1982;217:855-7.

7 Goldstein LB, Davis JN. Clonidine impairs recovery of beam-walking in rats. Brain Res 1990;508:305-9.

8 Schallert T, Hernandez TD, Barth TM. Recovery of function after brain damage: severe and chronic disruption by diazepam. Brain Res 1986;379:104-11.

9 Feeney DM, Hovda DA. Reinstatement of binocular depth perception by amphetamine and visual experience after visual cortex ablation. Brain Res 1985;342:352-6.

10 Hovda DA, Sutton RL, Feeney DM. Amphetamineinduced recovery of visual cliff performance after bilateral visual cortex ablation in cats: measurements of
depth perception thresholds. Behav Neurosi 1989;103: 574-84.

11 Feeney DM, Gonzalez A, Law WA. Amphetamine restores locomotor function after motor cortex injury in the rat. Proc West Pharmacol Soc 1981;24:15-7.

12 Hovda DA, Feeney DM. Amphetamine with experience promotes recovery of locomotor function after unilateral promotes recovery of locomotor function after unilateral 358-61.

13 Meyer PM, Horel JA, Meyer DR. Effects of dl-amphetamine upon placing responses in neodecorticate cats. f Comp Physiol Psych 1963;56:402-4.

14 Sutton RI, Hovda DA, Feeney DM. Amphetamine accelerates recovery of locomotor function following bilateral frontal cortex ablation in cats. Behav Neurosci 1989; 103:837-41.

15 Goldstein LB. Pharmacology of recovery after stroke. Stroke 1990;21 (suppl III):III-139-42.
16 Hovda DA, Feeney DM. Haloperidol blocks amphetamine induced recovery of binocular depth perception after bilateral visual cortex ablation in the cat. Proc West Pharmacol Soc 1985;28:209-11.

17 Feeney DM, Westerberg VS. Norepinephrine and brain damage: alpha noradrenergic pharmacology alters functional recovery

18 Goldstein LB. Amphetamine-facilitated functional recovery after stroke. In: Ginsberg $\mathrm{MD}$, et al, eds Cerebrovascular diseases, sixteenth research (Princeton) conference. New York: Raven Press, 1989:303-8.

19 Goldstein LB, Poe HV, Davis JN. An animal model of recovery of function after stroke: facilitation of recovery by an a2-adrenergic receptor antagonist. Ann Neurol 1989;26:157.

20 Sutton RL, Feeney DM. a-Noradrenergic agonists and antagonists affect recovery and maintenance of beamwalking ability after sensorimotor cortex ablation in the rat. Restorative Neurology and Neuroscience 1992;4:1-11.

21 Stephens J, Goldberg G, Demopoulos JT. Clonidine reinstates deficits following recovery from sensorimotor corstates deficits following recovery from sensorimotor cor-

22 Brailowsky S, Knight RT, Blood K. $\gamma$-aminobutyric acidinduced potentiation of cortical hemiplegia. Brain Res 1986;362:322-30

23 Brailowsky S, Knight RT, Efron R. Phenytoin increases the severity of cortical hemiplegia in rats. Brain Res 1986;376:71-7.

24 Chweh AY, Swinyard EA, Wolf HH. Involvement of a GABAergic mechanism in the pharmacologic action of phenytoin. Pharmacol Biochem Behav 1986;24:1301-4.

25 Hernandez TD, Holling LC. Disruption of behavioral recovery by the anti-convulsant phenobarbital. Brain Res 1994;635:300-306.

26 Schallert T, Jones TA, Weaver MS, Shapiro LE, Crippens $D$, Fulton R. Pharmacologic and anatomic consideraions in recovery of function. Physical Medicine and tions in recovery of function.

27 Hayes RL, Lyeth BG, Dixon CE, Stonnington $\mathrm{HH}$ Becker DP. Cholinergic antagonist reduces neurologic deficits following cerebral concussion in the rat. $\mathcal{F}$ Cereb Blood Flow Metab 1985;5 (suppl 1):S395-96.

28 De Ryck M, Duytschaever H, Janssen PAJ. Ionic channels, cholinergic mechanisms, and recovery of sensorimotor function after neocortical infarcts in rats. Stroke 1990;21 (suppl III):III-158-63.

29 Saponjic RM, Barbay S, Hoane MR, Irish SL, Barth TM. Scopolamine facilitates recovery of forelimb placing behavior following unilateral cortical lesions in the rat. Society for Neuroscience Abstracts 1993;19:1012.

30 Barth TM, Grant ML, Schallert T. Effects of MK-801 on recovery from sensorimotor cortex lesions. Strok 1990;21 (suppl III):III-153-7.

31 Barbay S, Barth TM. Multiple injections of MK-801 after recovery from lesions in the somatic sensorimotor cortex reinstate forelimb placing deficits in the rat. Society for Neuroscience Abstracts 1993;19:1012.

32 Crisostomo EA, Duncan PW, Propst MA, Dawson DB Davis JN. Evidence that amphetamine with physica therapy promotes recovery of motor function in stroke patients. Ann Neurol 1988;23:94-7.

33 Walker-Batson D, Unwin H, Curtis $\mathrm{S}$, et al. Use of amphetamine in the treatment of aphasia. Restorative Neurology and Neuroscience 1992;4:47-50.

34 Goldstein LB, Matchar DB, Morgenlander JC, Davis JN. The influence of drugs on the recovery of sensorimotor The influence of drugs on the recovery of sensorimotor
function after stroke. fournal of Neurological Rehabilitation 1990;4:137-44.

35 Porch BE, Feeney DM. Effects of antihypertensive drugs on recovery from aphasia. Clin Aphasiology 1986;16

36 Goldstein LB, SASS Study Investigators. Common drugs may influence motor recovery after stroke. Neurology 1995 (in press)

37 van Woerkom TCAM, Minderhoud JM, Gottschal T, Nicolai G. Neurotransmitters in the treatment of patients with severe head injuries. Eur Neurol 1982;21: 227-34.

38 Evans RW, Gualtieri CT, Patterson D. Treatment of closed head injury with psychostimulant drugs: a controlled case study in an appropriate evaluation procetrolled case study in an appropriate ev
dure. $\mathcal{F}$ Nerv Ment Dis 1987;175:106-10.

39 Dikmen SS, Temkin NR, Miller B, Machamer J, Winn R Neurobehavioral effects of phenytoin prophylaxis of Neurobehavioral effects of phenytoin prophyla
posttraumatic seizures. $\mathcal{F} A M A 1991 ; 265: 1271-7$.

40 Goldstein LB, Davis JN. Physician prescribing patterns after ischemic stroke. Neurology 1988;38:1806-9.

41 Jennett B, Bond M. Assessment of outcome after severe brain damage. A practical scale. Lancet 1975;i:480-4.

42 Smith KR Jr, Goulding PM, Wilderman D, Goldfade PR, Holterman-Hommes P, Wei F. Neurobehavioral effects of phenytoin and carbamazepine in patients recovering from brain trauma: a comparative study. Arch Neurol 1994;51:653-60.

43 Rao N, Jellinek HM, Woolstin DC. Agitation in closed head injury: haloperidol effects on rehabilitation outcome. Arch Phys Med Rehabil 1985;66:30-4.

44 Lipper S, Tuchman MM. Treatment of chronic posttraumatic organic brain syndrome with dextroamphetamine: first reported case. $₹$ Nerv Ment Dis 1976; mine: first

45 Gualtieri T, Chandler M, Coons TB, Brown LT Amantadine: a new clinical profile for traumatic brain injury. Clin Neuropharmacol 1989;12:258-70. 